\title{
Tax Payers' Perception Towards the Existing Tax System in Ethiopia: The Case of North Shewa Zone, Ethiopia
}

\author{
Yalemselam Worku* Amogne Mamaw Abebaw Fisseha Grima Zeleke \\ Debre Berhan University, Department of Accounting and Finance, Debre Berhan, Ethiopia
}

\begin{abstract}
The objective of this study was to examine taxpayers' perception towards the excising tax system in Ethiopia in general and North Shewa Zone, Amhara Regional State in particular. The study used descriptive research design. Category "B" tax payers were the target population of this study. A sample of 317 individual Category "B" tax payers were randomly taken from selected cities and woredas of North Shewa Zone, Amhara Regional State. Both primary and secondary data sources were used for the study. Primary data were collected through questionnaire and secondary data were collected from reports and manuals of the Ethiopian Revenue and Customs Authority (ERCA) branch offices. Descriptive statistics such as tables and percentages have been used for data analysis. The result of this study revealed that North Shewa Zone Category "B" individual taxpayers' perceive the tax they are paying is unfair. Moreover, most of the respondents' point out the complexity of the tax system. Generally, the result of the study showed the importance of taking measures to improve the existing tax system through developing simple and transparent tax collection systems, building trust and confidence with taxpayers' to increase the positive perception of taxpayers' towards the existing tax system.
\end{abstract}

Keywords: Tax fairness, Tax complexity, North Shewa Zone, and Ethiopia

DOI: $10.7176 /$ RJFA/10-3-03

\section{Introduction}

Tax is an important source of government revenue to finance expenditures on goods and services that can help to create employment, fight inflation and stimulate economic growth. As in all other countries, one of the purposes of taxation in Ethiopia is the raising of as much revenue as possible to meet the ever increasing public expenditure for the supply of public goods and services which otherwise would not be available to the general public by the market (Yohannes \& Sisay, 2009).

A perception of fairness and trust are important tools for a tax administration in attempting to reduce incompliance. The key to establishing trust is to frame the collection of taxes to the population in a transparent manner and emphasize the perceived fairness of the approach taken. Norms and the motivation to pay taxes are influenced by fairness both in how a person is treated by the administration individually and perceptions of fairness of the taxation system in general (whether other people are also paying their fair share). If a tax administration can demonstrate its commitment in these areas, there will be a compliance benefit (Reeson et al., 2009). Taxation in accordance with appropriately applied standards of ability to pay or benefits received is said to meet the requirements of vertical equity because such taxation exacts different amounts from people in different situations. Just as important is horizontal equity - the principle that people who are equally able to pay and who benefit equally should be taxed equally. Both "ability to pay "and "benefits received", therefore, are criteria of fairness (Parameswaran, 2005).

Tax complexity may be responsible for the misperception of the tax system. In this study, tax complexity is understood from two dimensions i.e. excessive detail in the tax rules and numerous computations required. With this regard Adams (1921) states that, the success of income tax rests primarily upon the honesty of the taxpayers and one of the factors that contribute to dishonesty in taxpayers is the complexity of the tax system as it may lead to administrative failures. As the tax law has become increasingly complex, complexity has come to recognize as a possible reason for tax payers' misperception thereby for tax noncompliance (Jackson \& Milliron, 1986).

In general, understanding of taxpayers' perception towards the tax system that can influence compliance will bring more revenue and less administrative cost to the tax authority (Anna \& Kamala, 2008). Therefore, a study on taxpayers' perceptions towards the tax system is important. Hence, this study mainly intends to examine taxpayers' perception towards the existing tax system in Ethiopia with a particular emphasis of individual business income taxpayers' in North Shewa Zone, Amhara Regional State.

\section{Statement of the Problem}

Ethiopia is a country that comprises a diverse collection of cultures, languages, beliefs and backgrounds. It is conceivable that these different population groups may have differing perceptions of taxation resulting from their cultural backgrounds or even their political and social histories. According to Fochmann et al., (2010), these perceptions may, in turn, influence their attitudes towards the tax system. If taxpayers' perceptions influence their attitudes towards tax system, it can be concluded that it is important to investigate the tax payers' perception and focus on changing their perception towards taxation in order to achieve a more positive attitude 
towards the system.

As we all known, there is a substantial tax gap between the tax that is theoretically collectable from economically active persons and the tax that is actually collected. One of the main reasons for the tax gap is misperception by taxpayers and potential taxpayers towards the tax system. It is therefore utmost importance to determine taxpayers' perceptions towards taxation, not only to influence government policy regarding taxation and protecting the country's tax base but also to enable government to provide its services more effectively to the general public (Martin et.al., 2010).

Since taxpayers' perception towards the tax system has a serious influence on their compliance with the tax law, a study on taxpayers' perceptions is important. There are a number of studies conducted on tax payers' perception towards tax systems across the world. For instance, Abdulhadi et al., (2008), Roberts \& Hite (1994), Amitai Etzioni (1986), and Trevor Manuel (1999), have done studies regarding tax payers' perception on different countries. However, there are a limited number of studies in Ethiopia related to the issue. Moreover, the studies in Ethiopia tried to investigate the tax payers' perception towards particular point of the tax system. As per the researcher's knowledge, no study is conducted to examine the taxpayers' perception towards the existing tax system in relation to tax fairness and tax complexity simultaneously. Thus, by taking this in to account and some other knowledge gaps and keeping the results or findings of the former studies, the researcher's attempts to examine the tax payers' perception towards the existing tax system in relation to tax fairness and complexity in Ethiopia with a particular emphasis of individual business income taxpayers' in North Shewa Zone, Amhara Regional State.

\section{Objectives of the Study}

The objective of this study is to investigate individual business income taxpayers' perception, complex towards tax fairness.

\section{Related Literature Review}

Using survey instrument with a sample size of 200, Wubshet (2011) investigate that, Addis Ababa business profit taxpayers viewed the current business profit tax system as reasonably fair in terms of horizontal fairness, but not on vertical fairness, personal fairness, administrative fairness, exchange fairness, and general fairness. In addition to this, Wubshet examines that there is no difference in level of fairness perceptions among Addis Ababa city business profit taxpayers towards the current income tax system.

A study entitled as "Progressive Taxation, Fairness, and Compliance" carried out by Roberts \& Hite (1994), examined the preferences for income tax progressively, other tax fairness issues, and tax compliance. This study revealed that mean public preferences for fair tax burdens are close to actual effective tax rates. The study sample was about 600 households and classified into three groups: (1) those who believe that tax rates should be higher for upper income persons (steep progressives), (2) those who prefer mildly progressive tax rates (mild progressives), and (3) those who believe tax rates should be flat (flatters). Moreover, the study surveyed the tax fairness attitudes of the income tax, exchange equity with the federal government, government spending, tax complexity, and tax compliance. One important conclusion to this study is that there is a relatively high consensus among respondents that the income tax is unfair, especially with regard to the ability of wealthy taxpayers to exploit loopholes to avoid paying their fair share, and that respondents regard their own tax burdens as unfair.

Grant Richardson (2004) carried out a comparison study of the tax fairness perceptions and taxpayers' compliance between Australia and Hong Kong in his study titled as "An exploratory cross-cultural study of tax fairness perceptions and tax compliance behavior in Australia and Hong-Kong". As a result of his study, Richardson found that there are different facets of tax fairness perceptions have distinct impacts across jurisdictions. Through his study, Richardson made a support for the view that there seems to be no universal relationships or patterns that necessarily exist between the different facets of tax fairness perceptions and tax compliance behavior cross-culturally.

Along the same lines, Rupert and Wright (1998) use four different presentation forms of a tax scale which differ in the visibility of marginal tax rates. These authors also show that a higher visibility of marginal tax rates leads to better investment decisions. With an experiment, Rupert et al. (2003) analyze to what extent a more complex tax system influences the perception of marginal tax rates and the decision making process of an individual. Complexity is measured by the limitation of possible tax deductions in a tax system. Therefore, the more limitations exist the more complex is the tax system. The limitations are chosen in such a way that the effective marginal tax rate is the same for all treatments independent of the complexity of the respective tax regime. The authors show that subjects in the more complex tax systems are not able to estimate their effective marginal tax rates accurately. The results suggest that subjects do not adjust their estimates to account for the effects of limitations and, therefore, undervalue their true marginal tax rate. An increase of complexity leads to more misperceptions. As a result of this misperception, participants in the more complex treatments choose the 
optimal investment less frequently. Thus, low complexity leads to a better performance and to more efficiency.

Blaufus and Ortlieb (2009) examine complexity's influence on individual decisions with a conjoint analysis. In this study, higher tax complexity is achieved with an increase of tax compliance costs measured by the time participants needed to understand the respective tax regime. Therefore, the length of the tax instructions and the number of technical terms, calculating operations and cross references are varied. The authors show that subjects base their decisions less often on their after-tax return if tax complexity is high. However, even in a low complexity tax system subjects often do not calculate their after-tax return but base their decisions on the advice offered by a third party in the interview.

\section{Methodology}

\section{Population, Sampling Method and Sample Size}

The study used purposive and random sampling techniques for collecting data from individual tax payers. Purposive sampling was employed to select eight woredas/cities of North Shewa Zone. Individual business income tax payers were randomly selected using equal proportion in each woredas/cities using random sampling technique. In year 2017 there were about 1527 Category "B" tax payers in all selected woredas/cities. The researchers have used 317 samples from the total population of 1527.

\section{Methods of Data Analysis and Presentation}

The descriptive analysis showed how the taxpayers perceive the existing tax system in relation to tax fairness and tax complexity. In this analysis, the frequency distribution was determined and the results were presented using tabulations and percentages.

\section{Results and Discussion}

The following section presents the perceptions of different tax payers which are participated in the questionnaire and a conclusion was drawn based on the information gathered.

Table 1: Frequency distribution of tax fairness perception of respondents in the sample

\begin{tabular}{lccrr}
\hline & Frequency & Percent & Valid Percent & $\begin{array}{c}\text { Cumulative } \\
\text { Percent }\end{array}$ \\
\hline The amount of tax I am paying is fair and based on my ability to pay & & & \\
Strongly Disagree & 36 & 11.7 & 11.7 & 11.7 \\
Disagree & 121 & 39.3 & 39.3 & 51 \\
Neutral & 42 & 13.6 & 13.6 & 64.6 \\
Agree & 94 & 30.5 & 30.5 & 95.1 \\
Strongly Agree & 15 & 4.9 & 4.9 & 100 \\
\hline
\end{tabular}

Source: Questionnaire, 2017

According to the data collected from the questionnaire, 30.5 percent of the respondent believe that they made to pay as balanced as their ability to pay and concluded that the tax payment is made fair to them. However, about 39.3 percent believe the opposite and they believe that they are forced to pay beyond their capacity and unfair tax. Similar to the above cases, 13.6 percent assumed that the tax payment neither more than their capacity nor it is as balanced as the capacity or ability they have. They simply responded as being neutral not to say something about the fairness with regard their ability to pay. Generally speaking, of the respondents, 51 percent have said that the tax they are paying is unfair. Besides, 11.7 percent and 4.9 percent of them have mentioned their strong disagreement and strong agreement respectively with regard their ability to pay and the fairness of the tax system.

Table 2: Frequency distribution of tax fairness perception of respondents in the sample

\begin{tabular}{lcccr}
\hline & Frequency & Percent & Valid Percent & Cumulative Percent \\
\hline Higher income earners should pay more taxes than lower income earners & 6.5 & 6.5 \\
Strongly Disagree & 20 & 6.5 & 13.3 & 19.8 \\
Disagree & 41 & 13.3 & 9.1 & 28.9 \\
Neutral & 28 & 9.1 & 48.7 & 77.6 \\
Agree & 150 & 48.7 & 22.4 & 100 \\
\hline Strongly Agree & 69 & 22.4 & &
\end{tabular}

Source: Questionnaire, 2017

It is also indicated in Table 2 above that about 48.7 percent of the participants have agreed those companies that gains higher level of income need to pay high amount of income tax compared to those companies earning less amount of income. Those who disagree on the idea of higher earners should pay higher taxes and those who strongly agree on the same point accounts for 13.3 percent and 22.4 percent respectively. Generally speaking, of the respondents, 71.1 percent have agreed on the progressive nature of 
the income tax whereas about 19.8 percent have decided not to agree with it. And the remaining 9.1 percent decides to be neutral which implies they are indifferent whether higher earners pays higher level of income tax or not.

Table 3: Frequency distribution of tax fairness perception of respondents in the sample

\begin{tabular}{lrrrr}
\hline & Frequency & Percent & Valid Percent & Cumulative Percent \\
\hline It is unlikely that I will be caught when evading taxes & & & \\
Strongly Disagree & 35 & 11.3 & 11.3 & 11.3 \\
Disagree & 72 & 23.4 & 23.4 & 34.7 \\
Neutral & 70 & 22.7 & 22.7 & 57.4 \\
Agree & 112 & 36.4 & 36.4 & 93.8 \\
Strongly Agree & 19 & 6.2 & 6.2 & 100 \\
\hline
\end{tabular}

Source: Questionnaire, 2017

Table 3 also indicates that there is higher probability of not being caught when they evade their taxes deliberately because huge number of the respondent which is about 36.4 percent have answered that there is less likely to be caught. It can be due to the fact that they have the experience of evading taxes in their past experience and did not found caught by the authority. 22.7 percent of the respondents have decided to be neutral which implies that they might be in the practices of evading and that is why they decided not to clearly specify their answer. In contrast to this, 23.4 percent of the respondents have indicated that it is not unlikely not to be caught when anybody evades.

Table 4: Frequency distribution of tax fairness perception of respondents in the sample

\begin{tabular}{lrrrr}
\hline & Frequency & Percent & Valid Percent & Cumulative Percent \\
\hline \multicolumn{2}{l}{ Tax evasion is ethical if the tax system is unfair } & & & \\
Strongly Disagree & 22 & 7.2 & 7.2 & 7.2 \\
Disagree & 58 & 18.8 & 18.8 & 26 \\
Neutral & 49 & 15.9 & 15.9 & 41.9 \\
Agree & 135 & 43.8 & 43.8 & 85.7 \\
Strongly Agree & 44 & 14.3 & 14.3 & 100 \\
\hline
\end{tabular}

Source: Questionnaire, 2017

Tax fairness and tax evasion are basically two different things and literally it is recommendable to conclude that tax should be evaded if it is not fair. It is simply correcting a failure with a mistake which exacerbates the problem on the ground. However majority of the respondent which are about 43.8 percent have indicated that tax needs to be evaded provided that the tax system is not fair enough and about 18.8 percent responded that they will disagree on the statement tax evasion is ethical if the tax system is unfair.

Table 5: Frequency distribution of tax complexity degree of respondents in the sample

\begin{tabular}{lccrr}
\hline & Frequency & Percent & Valid Percent & Cumulative Percent \\
\hline The Ethiopian business income tax system & is too complicated & & \\
Strongly Disagree & 13 & 4.2 & 4.2 & 4.2 \\
Disagree & 42 & 13.6 & 13.6 & 17.8 \\
Neutral & 22 & 7.1 & 7.1 & 24.9 \\
Agree & 198 & 64.3 & 64.3 & 89.2 \\
Strongly Agree & 33 & 10.7 & 10.7 & 100 \\
\hline
\end{tabular}

Source: Questionnaire, 2017

As it is indicted in Table 5, majority of the respondents have perceived that the Ethiopian business income tax is too complicated which does not easy to understand. To mention the magnitude, 75 percent of them found the business profit tax to be complicated and about only 17.8 percent have found it clear and not difficult.

Table 6: Frequency distribution of tax complexity degree of respondents in the sample

\begin{tabular}{lcccr}
\hline & Frequency & Percent & Valid Percent & Cumulative Percent \\
\hline The Ethiopian business income tax rules are & bulky and hard for taxpayers like us to navigate & 3.8 \\
Strongly Disagree & 12 & 3.8 & 3.8 & 12.6 \\
Disagree & 27 & 8.8 & 8.8 & 27.2 \\
Neutral & 45 & 14.6 & 14.6 & 88.6 \\
Agree & 189 & 61.4 & 61.4 & 100 \\
\hline Strongly Agree & 35 & 11.4 & 11.4 & \\
\hline
\end{tabular}

Source: Questionnaire, 2017

Similarly, majority of the respondents have perceived that the Ethiopian business income tax rules are bulky and hard for taxpayers like us to navigate. To mention the magnitude, 72.8 percent of them found the business profit tax rules are bulky and hard for taxpayers like us to navigate and about only 12 percent have 
responded the other way.

Table 7: Frequency distribution of tax complexity degree of respondents in the sample

\begin{tabular}{lcrrr}
\hline & Frequency & Percent & Valid Percent & $\begin{array}{c}\text { Cumulative } \\
\text { Percent }\end{array}$ \\
\hline The tax system is transparent and understandable to taxpayers & & & \\
Strongly Disagree & 60 & 19.5 & 19.5 & 19.5 \\
Disagree & 138 & 44.8 & 44.8 & 64.3 \\
Neutral & 13 & 4.2 & 4.2 & 68.5 \\
Agree & 83 & 26.9 & 26.9 & 95.4 \\
Strongly Agree & 14 & 4.6 & 4.6 & 100 \\
\hline
\end{tabular}

Source: Questionnaire, 2017

Tax system need to be transparent easily understandable to tax payers as far as possible and majority which are about only 31.5 percent of them have explained that the tax system of the country is recognizable and transparent to the public. In contrast to this, 64.3 percent of the respondents have explained their disagreement on the degree of transparency of the tax system while the remaining 4.2 percent kept neutral to share their view on the understandability and transparency of Ethiopian tax system. This show the transparence issues are main constraint for the taxpayers and expect more attention from the government side to avoid the problem.

So far, the study has attempted to analyze the perception of tax payers on the existing tax system of the country. According to the data collected from the respondents in the following section, possible solutions recommended by the participants are presented.

Table 8: Frequency distribution of possible solutions forwarded by the respondents

\begin{tabular}{|c|c|c|c|c|c|c|c|}
\hline & & $\begin{array}{l}\text { Strongly } \\
\text { Disagree }\end{array}$ & Disagree & Neutral & Agree & $\begin{array}{c}\text { Strongly } \\
\text { Agree }\end{array}$ & Total \\
\hline \multirow{2}{*}{$\begin{array}{l}\text { Develop simple transparent } \\
\text { tax collection systems }\end{array}$} & Freq. & 7 & 16 & 18 & 196 & 71 & 308 \\
\hline & Percent & 2.3 & 5.2 & 5.8 & 63.6 & 23.1 & 100 \\
\hline \multirow{2}{*}{$\begin{array}{l}\text { Building trust and } \\
\text { confidence with taxpayers }\end{array}$} & Freq. & 2 & 25 & 28 & 181 & 72 & 308 \\
\hline & Percent & 0.6 & 8.1 & 9.1 & 58.8 & 23.4 & 100 \\
\hline \multirow{2}{*}{$\begin{array}{l}\text { Treats everyone in the } \\
\text { same manner }\end{array}$} & Freq. & 8 & 20 & 21 & 170 & 89 & 308 \\
\hline & Percent & 2.6 & 6.5 & 6.8 & 55.2 & 28.9 & 100 \\
\hline \multirow[t]{2}{*}{ Reducing tax rates } & Freq. & 29 & 39 & 35 & 168 & 37 & 308 \\
\hline & Percent & 9.4 & 12.7 & 11.4 & 54.5 & 12 & 100 \\
\hline \multirow{2}{*}{$\begin{array}{l}\text { Strengthening legal } \\
\text { enforcement and penalties }\end{array}$} & Freq. & 10 & 25 & 27 & 184 & 62 & 308 \\
\hline & Percent & 3.3 & 8.1 & 8.8 & 59.7 & 20.1 & 100 \\
\hline
\end{tabular}

Table 8 above indicates that majority of the respondents explained different measurements should be taken in to action for the good working environment as well as better perception of taxpayers. To mention about 86.7 percent of the respondents have agreed that developing simple and transparent tax collection systems is a possible solution to improve and solve the problems observed in the previous sections. Only 7.5 percent of the respondents explained the reverse.

Similarly, the respondents have also indicated that building trust and confidence with taxpayers' and treating everyone in the same manner will also be a possible solution forwarded with a share of about 82.2 percent and 84.1 percent, respectively. Only 8.7 percent and 9.1 percent of them responds perceived the other way, which means either another strong methodology should be adopted to tackle the problems or those are in practices in the tax system of the country.

Strengthening legal enforcement and penalties and reducing tax rates are also among the commonly agreed strategies to be taken so that the problems of tax system and the perception of tax payers will be easily corrected.

\section{Conclusion}

The result from this study provides valuable insight about the perception of Category " $\mathrm{B}$ " business income taxpayers in North Shewa Zone. The study provides awareness of the issues that are needed to be addressed and suggested solutions in order for the tax authorities and other decision makers at various governmental levels (e.g. regional or local) to understand the taxpayers concerns and perception on tax system and improve the system in order to increase taxpayers' voluntary compliance.

About 71.1 percent of the respondents have agreed on the progressive nature of the income tax where the higher income earners should pay higher amount of taxes whereas still about 19.8 percent have decided not to agree with it which is insignificant figure.

Tax payers were also asked about the simplicity of tax returns and administration and more than half of tax 
payers replied that, the existing tax system is complex and if the tax system becomes easy it encourages them to voluntary comply with tax laws. Tax payers were also asked about their perception on tax fairness and equity. Most of tax payers believed that the current Ethiopian tax system is not fair.

Developing simple and transparent tax collection systems, building trust and confidence with taxpayers' and treating everyone in the same manner, strengthening legal enforcement and penalties and reducing tax rates are among the commonly agreed strategies by the respondents to be taken by tax authorities so that the problems of tax system and the perception of tax payers will be easily corrected.

\section{References}

Adams, T.S. (1921). Fundamental problems of federal Income Taxation.Quarterly Journal of Economics 35(4), 527-557. AbdulhadiKhasawneh, Mohammed Ibrahim Obeidat, Mohamed

AmitaiEtzioni .(1980).Tax evasion and perceptions of tax fairness; a research note

Anna A. CheAzmi and Kamala A. Perumal, (2008) Tax Fairness Dimensions In An Asian Context: The Malaysian Perspective; International Review of Business Research Papers Vol. 4 No.5 October-November 2008 Pp.11-19

Fochmann, M., D. Kiesewetter and A. Sadrieh (2010a), 'Investment Behavior and the Biased Perception of Limited Loss Deduction in Income Taxation', FEMM Working Paper, No. 04.

Grant Richardson, (2005), An Exploratory Cross-Cultural Study of Tax Fairness Perceptions and Tax Compliance Behavior in Australia and Hong Kong”, International Tax Journal, pp, 11-27.

Jackson, B.R., \&Milliron V.C. (1986), “Tax compliance research, findings and problems and prospects", Journal of Accounting Research, Vol5, pp. 125-165

Rupert, T. J. and A. M. Wright (1998), 'The Use of Marginal Tax Rates in Decision Making:The Impact of Tax Rate Visibility', Journal of the American Taxation Association 20, 83-99.

Reeson, A. and Dunstall, S. (2009), Behavioural Economics and Complex Decision-Making: Implications for the Australian Tax and Transfer System, CSIRO / CMIS Report No. 09/110.

WubshetAborat .(2011).Taxpayers' Perception towards Fairness: Personal Business Profit Taxpayers in Addis Ababa, research note

Yohannes Mesfin\&SisayBogale (2008) Teaching Material,Prepared under the Sponsorship of the Justice and Legal System Research Institute 